\title{
NATIONAL LANGUAGE IN SCIENCE: THE CASE OF LATVIAN
}

\author{
AGNESE DUBOVA \\ Faculty of Translation Studies, Ventspils University of Applied Sciences \\ Inženieru 101, 3601 Ventspils \\ E-mail address: agnesed@venta.lv \\ ORCID number: https://orcid.org/0000-0002-7428-1824
}

\section{DIĀNA LAIVENIECE}

Faculty of Humanitarian Science and Arts

Liepaja University

Kūrmājas prospekts 13, 3401 Liepāja

E-mail adress: diantra@gmail.com

ORCID number: https://orcid.org/0000-0002-3107-2109

EGITA PROVEJA

Faculty of Translation Studies

Ventspils University of Applied Sciences

Inženieru 101, 3601 Ventspils

E-mail adress: egita.proveja@venta.lv

ORCID number: https://orcid.org/0000-0002-5220-7797

\author{
BAIBA EGLE \\ Faculty of Translation Studies \\ Ventspils University of Applied Sciences \\ Inženieru 101, 3601 Ventspils \\ E-mail address: baiba.egle@venta.lv \\ ORCID number: https://orcid.org/0000-0002-6207-7789
}

\begin{abstract}
Aim. To show and describe the current situation in Latvian language as a case study of the problem about the place of a national language and its existence in sciences in modern globalised times, when the dominance of English as the lingua franca of science grows.

Methods. A descriptive method, including literature review of language of science used globally. Empirical discourse content analysis was conducted; it examined various documents, including Latvian legal texts that governs the rights and rules of Latvian language use, as well as a wide array of mainly online media.
\end{abstract}


Results. During the study, 21 different sources and 304 online comments under articles relating to the issue were analysed. The material revealed that there is a breadth of opinions, ranging from the Ministry stance to organisations and the general public. It could be said that the main trend in the opinions can be described as follows: there is a variety of language options - a dissertation written only in Latvian; a dissertation written in English; a choice of language that is up to the doctoral student. This would ensure that the language choice fits the doctoral students' goals and field of research and making English mandatory would not likely lead to guaranteed scientific excellence as what matters is the research itself, not the language.

Conclusions. National language of science is a current issue in Latvia, as there is a need for state language use in the scientific register. The discussed Ministry document is still a draft report and it is not yet known what final decisions on the $\mathrm{PhD}$ process and dissertation language will be taken. Latvian is a scientific language and it should be recognised as one of the languages used in science within the international scientific discourse.

Key words: language use in science, national language, Latvian, English, dissertation defense.

$\mathrm{T}$ This research is funded by the Latvian Council of Science, project "Intra-lingual Aspects of the Latvian Scientific Language", project No. lzp-2018/2-0131. Academic discipline and sub-disciplines - linguistics.

\section{INTRODUCTION}

A scientist from any given field does not work in an isolated bubble with only his or her work, without any external influence. Latvian scientists also face myriad of challenges regarding language use and choice that have not been discussed enough within both the academic and public environment until recently.

The global dominance of English in scholarly publishing has implications for international higher education along two main lines: (1) for stakeholders of scholarly publication and participation in international academic conferences to understand the challenges that multilingual scholars confront; and (2) for national governmental and institutional policymaking bodies to consider the effects of the premium placed on English-medium journal publishing (Curry \& Lillis 2007). However, these points do not guide the way in which a national language can survive in the global science world.

The paper examines a relatively short time frame (altogether around 20 days in November and December of 2019) within the Latvian academic and media space when the question about the existence and importance of Latvian in the country where it is the official state language was raised with never before seen tension, threatening to become a national conflict between the governmental institution (The Ministry of Science and Education of the Republic of Latvia, further in the text referred as the Ministry) and the intelligentsia.

The aim of this paper is to show and describe the current situation in the Latvian scientific language as a case study of the problem of the place of a natio- 
nal language and its existence in science in modern globalised time, where the dominance of English as the lingua franca of science grows.

To achieve this aim, a descriptive method and empirical discourse content analysis were used through examining various documents, including Latvian law that governs the rights and rules of the use of Latvian language; a wide array of media were also examined by extraction of the most important for and against opinions regarding Latvian as a language of science and its future within the doctoral dissertation process and the language of the dissertation which is in all, a significant process for science, research and terminology development.

\section{PUBLISH OR PERISH - ONLY IN ENGLISH?}

Ideally, the native English speakers would be more understanding towards the non-native English speakers and help the non-natives learn how to move in the Anglophone scientific publication world. But that is not often the case as it is expected that a person just knows how to publish in English without much instruction.

The significance of the English-language publications is often implicit: where the work is indexed and which database or which journal it is published in. Often only papers written in English get indexed and it increases the need for a person to publish in English to reach targets set by their own institution or government.

There is increasing pressure to publish research as often as possible: this problem was already discussed in 1989 (Wheeler, 1989) but still is very persistent, as Katie Langin (2019) notes that today there are over 30000 academic journals available. This number is divided by all disciplines of science, which still leave hundreds, if not thousands of possible journals in which one could publish their papers. Many Latvian higher education institutions also publish journals, conference proceedings and other materials that add to this number. Some of these Latvian institution publications are in Latvian, some allow English and/or other languages. Bilingual publications (Latvian and English) and multilingual (usually in Latvian, Lithuanian, English, German, Russian, less often also in French or Spanish) are also becoming more popular.

Currently more and more publishing houses all around the world choose to publish materials only in English, indexations and ratings are better for English-language journals than foreign language journals. Every scientist wants their work to be seen and cited. Preferably worldwide. Philip G. Altbach (2013, p. 4) notes that "Scholars in other parts of the world must conform to the interests of the prestigious journals if they wish their work to be published in them". It is usually assumed that the prestigious journals are the ones published in English-speaking countries. However, Latvian journals have a societal importance as well, i.e. they aim to convey locally important research to academic peers and the general public that supports higher education institutions through tax money. 
Writing in English might seem like the answer to all problems. Most of papers in English will be indexed and seen. However, before publishing, there is a hurdle: getting the paper accepted. Ideally, all Latvian scientists would have English proficiency to such an advanced level that they could write their papers as easily in English as they do in Latvian. English very often is the second, or third or fourth language of an individual in Latvia.

Ideally, a scientist would have well balanced multilingualism: "a person who has proficiency in two languages such that his or her skills in each language match those of a native speaker of the same age" (APA, 2020), however, language learning and acquisition is a complex process. To acquire true Latvian-English multilingualism, with matching skills in both languages, would require a large investment of time and effort. Language is a complex issue especially in academic writing. Therefore, usage of a certain language over another should be balanced, without the eradication of the original culture to ensure that there is no "epistemicide", that is an eradication of local lore and knowledge (Bennet, 2015) and that the tendency to assume that everything written in English is based on the theory of knowledge in the Anglophone world (ibid.). While authors who write in English because of the need to publish in English hope that their work is well understood by native English speakers, there are many ways of conveying, writing down knowledge that are not always immediately translatable into English. In translation studies there is a belief that everything can be translated but a scientific text is a very special type that needs to be translated not only into the target language but also into the target academic culture. Thus, if a non-native English speaker hopes that hiring a translator eradicates language use problems, it would likely be not the perfect solution.

It seems that policy makers in Latvia sometimes only think about the aspect of research being international, and the only way to achieve it is to write in English and have attempted to implement more usage of English as discussed further in this article.

The European Commission (2014, p. 2) has a slightly different stance as it states that "Linguistic diversity is a fundamental component of European culture and intercultural dialogue, and that the ability to communicate in a language other than one's mother tongue is acknowledged to be one of the key competences which citizens should seek to acquire," but also highlights that "the linguistic landscape in the EU is complex and diverse, with national factors influencing language learning and teaching, and considerable differences in legislation and practice with regard to these".

These conclusions from the European Commission could be understood as that while it is a very desirable skill to know other languages and their usage, there is a lot of diversity in Europe. However, the rise of English as the lingua franca limits this diversity in academic writing.

Perhaps the right way to allow language diversity and still achieve targets set by policy is to have a balanced version of multilingualism, as suggested by Gunnar Sivertsen (2018): "balanced multilingualism is to consider all the com- 
munication purposes in all different areas of research, and all the languages needed to fulfil these purposes, in a holistic manner without exclusions or priorities". Based on this, it would be very useful to show the situation of the national language in science, as it happened in the final months of 2019 in Latvia and which was widely covered by media (including social media) that allowed everyone - governmental, non-governmental institutions, professional associations and every interested individual, including officials and university representatives and people in online communities to share their opinion about the place and existence of the Latvian language in doctoral dissertations.

\section{IN DEFENCE OF THE POSITION OF THE STATE LANGUAGE IN THE LATVIAN SCIENCE SPACE}

The issue of the position of the national language in science and research in the Latvian context escalated at the end of 2019, when a draft report by a Ministry working group became available on November, 12. The report was about the implementation of a conceptually new doctoral studies framework and new dissertation defence process in Latvia. The intention of the document was to introduce a new model of doctoral studies in Latvia and to create a new doctoral degree awarding system based on European best practice in order to promote research excellence in accordance with international standards. Discussions on the public debate on the new doctoral model were scheduled to take place soon after publishing the draft report - November 21, thus giving educational institutions insufficient time to study the concept, internal discussion and to formulate their views.

Among all the other innovations included in the model, academics as well as doctoral students are concerned about the section "Language of the Doctoral Thesis" of the conceptual report. It states: "given that the new defence process involves the participation of two foreign reviewers on the Doctoral Thesis Defence Board, the dissertation should be drafted in English or another international scientific language, depending on the field of the research being conducted" (IZM, 2019, p. 29).

The section adds that the dissertation can also be written in Latvian if the field and theme of the research requires it to be written in Latvian. In these cases, when the doctoral thesis is written in Latvian, it is necessary to meet pre-established and approved criteria that determine exactly in which cases the doctoral thesis in Latvian is admissible. However, even then, the scientific institution taking charge of the management of doctoral studies must ensure that the foreign reviewers of the Defence Board are able to evaluate the doctoral thesis - that is, if the work was written in Latvian, then it should be translated into English or foreign reviews with a sufficiently fluent command in Latvian should be sought so that they are capable to read and evaluate the text.

All of the above implies that as soon as this concept is approved, the Latvian language within the Latvian scientific space will be given only a marginal, 
secondary role compared to English. In essence, this would begin discrimination against the state language, which is completely contrary to the preamble of the Latvian Constitution, which states that The State of Latvia has been established "to guarantee the existence and development of the Latvian nation, its language and culture throughout the centuries", and Article 4 reads as follows: "the Latvian language is the official language in the Republic of Latvia" (The Constitution of the Republic of Latvia, 1922).

This position of the Ministry towards the state language undoubtedly generates widespread resonance among scientists, academics and general public, raising concerns about the threat of a new wave of linguicism towards the Latvian language. The argument put forward in the Ministry's document is that a PhD dissertation written in English, as well as a defence procedure involving at least two foreign reviewers that is done entirely in English, are a prerequisite for research excellence (IZM, 2019) so it implies that works written in Latvian are not eligible for excellence.

Linguicism is a term used in the 1992 work Linguistic Imperialism by Robert Phillipson to describe a process that represents the dominant language that has the desired attributes for inclusion purposes, and the opposite for the local language for exclusion purposes. Typical examples of binary opposition in linguistic discourse are language/dialect and also lingua franca/vernacular language. "(...) linguicism refers exclusively to ideologies and structures where language is the means of effecting or maintaining an unequal allocation of power and resources" (Phillipson 1992, p. 55).

Newspapers and Internet news portals, in response to the language choice of the dissertation defence process specified in the Ministry document, expressed their views using rather provocative headlines: A Funeral for the Latvian language? (Jundze, 2019, Nov 20); In the future, will Latvian be just used at home? (Kuzmina, 2019a, Nov 20); Intelligentsia is mobilizing to protect the official language (Vìksne, 2019, Nov 20); The Preamble and Article 4 of the Satversme must be urgently changed! (Paiders, 2019, Nov 22); Is science in Latvian provincial? (Zanders, 2019, Dec 2); The value of doctoral theses may be "lost in translation" (Čīka, 2019, Dec 8).

Based on the initiative of the Latvian Association for Applied Linguistics (LLVA), an initial open letter (LLVA, 2019a) for the defence of the rights of the Latvian language was sent to the Ministry, expressing serious concerns about the intentions regarding the state language in science and academia. The letter calls for not limiting the possibilities to implement the dissertation defence process in Latvian and to leave the language of the doctoral thesis as the doctoral student's choice.

At the discussion in November 21, when discussing the envisaged model of doctoral studies, there was not much said about the language issue, implying that the Ministry denies the importance of the issue and that the concerns expressed in the open letter were neither heard nor understood by the Ministry, the general public was invited to read and react to another open letter an Alert Letter (LLVA, 2019c) about an unprecedented threat to the future of the Latvian language. This letter was addressed to the President, the Prime 
Minister, the Cabinet and the Ministry of Education. Over the course of a few days, over 800 scholars, teachers, students, journalists, writers, poets, translators, actors, artists, cultural and public figures, and many representatives of the Lithuanian academic environment voiced their support for the open letter and, hence, the existence of Latvian as a language of science and education.

Both open letters explained why such a Ministry decision was completely unacceptable, considering the viability and prestige of the Latvian language as an official language. Main arguments were as follows:

- the abandonment of the official language in higher education and science will seriously undermine the overall status of the Latvian language, reducing the intensity and quality of language use, as shown by the negative experiences of Slovenia in the European Research Area;

- the weakening of one language function (in this case, the language of science) will endanger and affect the full implementation of other language functions; allowing the further development of the scientific language only in English will significantly impact the development of terminology in the national language, while the Latvian language of science as a whole will be simplified and degraded;

- abandoning the state language in the PhD process will diminish the importance and use of the Latvian language in higher education, which, in turn, will lower the motivation for qualitative language acquisition in schools in the long run it may have irreversible consequences for the existence of Latvian entirely.

Public discussions in the press, on TV, on websites, as well as on social networks revealed radically opposing views, with the emergence of another dangerous trend, namely the fragmentation of the Latvian scientific community, provoking a risk of another "war" between the natural sciences and the humanities because the suggestion to write and defend a dissertation in English came directly from natural sciences and engineering (Kuzmina, 2019a, Nov 20), which in turn will not be accepted by the social sciences and humanities.

But there is also a positive side to this, as it raises the issue of the mission of a scientist in Latvian society: to be seen in international science (global orientation) or to strengthen national science capacity to build a strong knowledge and education-oriented society and country ('glocal' orientation). The public defence may take its place in the official language or in any official language of the European Union Vice Rector Ina Druviete: "scientists aren't working just to become more internationally quoted and known. Any scientist, whether they are working in the social or natural sciences, works primarily for the Latvian society. Not only for the world, but also for their country" (Latvian Public Broadcasting/LTV 2019, Nov 20).

Glocalisation, which is a socio political, cultural and intellectual tendency opposite to globalisation (Runce, 2013), an adaptation of products and processes to a particular place (Muktupāvela, 2015), as well as understanding and synthesis of global and local values (Kasparāns, 2019), should be considered as a significant part in a country's scientific development goals. 
While defending the rights of Latvian in science and academia, the need for English in international scientific communication is not called into question, but neither does it advocate monolingual scientific communication, considering English as the only language suitable for science.

The Latvian Young Scientists' Association (LJZA), whose representatives have also participated in the development of the new doctoral studies model, came up with further arguments to defend the development of the doctoral research and the defence process in English: "science does not depend on the language it is discussed in. Scientific ideas can be discussed in any language of the world as long as those who know the language are able to understand them. That is why, in our opinion, the development of Latvian will depend on how competitive our new PhD graduates are once they finish education in our system" (LJZA, 2019, Dec 10). However, an express survey of LAS members on the language of the doctoral thesis shows that only $26 \%$ support the development of the doctoral thesis mainly in English, while the vast majority (63\% of respondents) believe that the choice of language should be left to the doctoral student (LZJA, 2019, Dec 10).

The current legislation of the Republic of Latvia also allows universities to decide independently and responsibly on the language in which the doctoral thesis is written, if it is not Latvian:

- Official Language Law - section 15: "the written work necessary to acquire the academic degrees shall be submitted in the official language or in a foreign language with an attached translation of an expanded summary in the official language. The public defence may take place in the official language or in a foreign language, in agreement with the author and acceptance by the relevant board for conferring academic degrees" (Official Language Law, 1999).

- Law on Scientific Activity - section 11, part 5: "the promotion thesis may be submitted in the official language or any of the official languages of the European Union, attaching thereto a translation of an extended summary of the promotion thesis in the official language (...). The submission and public defence of the promotion thesis for the acquisition of the doctoral degree in philology may also take place in a foreign language if the thesis is dedicated to the research of the relevant language" (Law of Scientific Activity, 2005).

With so much pressure from public opinion, the Ministry was forced to take action and, in early December, promised to preserve the state language in science (Anstrate, 2019, Dec 4).

On December 10, the Higher Education, Science and Innovation Subcommittee of the Saeima Education, Culture and Science Commission met to discuss the new doctoral model proposed by the Ministry. At this session the desired goal was achieved: Latvian retains its role as the language of the doctoral thesis writing and defence procedure in Latvia. If the doctoral programme is implemented in English or another official language of the European Union, the summary of the doctoral dissertation must be in Latvian. The requirement 
Journal of Education Culture and Society No. 1_2020

for a summary in Latvian also applies to the doctoral students from abroad (LLVA, 2019, Dec 11).

\section{LANGUAGE, QUALITY AND INTERNATIONALISATION OF THE DOCTORAL DISSERTATION}

Compromise was reached about the language of the doctoral thesis in discussion with Ministry, however, representatives of universities, research and public institutions in the public sphere express their views on the language of the doctoral thesis, which is mainly closely related to the status and development of the Latvian language in higher education and science, internationalisation of research and quality assessment.

Ken Hyland (2015, p. 52) writes that English as a dominant language threatens the national language in academic communication: "...the need for researchers to access this for their work serves to consolidate and strengthen English as the dominant language of publishing, placing many national languages at risk of losing an academic register (...)". According to K. Hyland (ibid.), the choice of language in scientific discourse is determined by the following:

"the factors that affect the choice of language are influenced by discipline, national policies, personal views on academic responsibilities, and individual attitudes regarding target communities, that is, attitudes and practices are more complex and multidimensional than the literature might suggest".

Moreover, in Latvia, several representatives of higher education, research and public institutions argue that the development of the Latvian language in science is an important issue; that in the case of all doctoral dissertations written only in one of the major foreign scientific languages (predominantly English), English would likely prevail as the main language of science used in Latvia and Latvian would weaken. Thus, a threat to the development of the Latvian language terminology is predicted because, according to Baltinšs, Director of the State Language Center, it is precisely in the "scientific works that new terms are created and practices of their use are established" (Vìksne, 2019, Nov 20). Threats to the structure and syntax and the status of the Latvian language as an official language and the language of science are also mentioned as possible risks if dissertations are to be written in English (Kuzmina 2019a, Nov 20; LLVA, 2019, Dec 10; LETA, 2019b, Dec 4).

The position of the Latvian in dissertation writing is also defended by the Independent Education Society, highlighting the convergence of research and school needs (Čìka, 2019, Dec 8). This is an important argument because the latest research findings must be included in Latvian textbooks and school research, thus ensuring knowledge transfer. Another reason for the defence of the Latvian language in the context of dissertation language is the issue of attitude towards the state language. There is an observation that Russian-speaking applicants for scientific degrees often do choose English as the language of the doctoral thesis, thus expressing a rather unfavourable attitude towards 
the Latvian language (Kuzmina, 2019b, Dec 8; LETA, 2019b, Dec 4). Writing a doctoral thesis in Latvian can promote a more positive attitude towards the Latvian language and also increase the prestige of the Latvian language.

In the European context there are examples of Slovenia and Scandinavia (Sweden), where English has become the standard language of science and the number of publications in national languages has fallen sharply (Vìksne, 2019, Nov 20; Kuzmina, 2019a, Nov 20). This fact is also confirmed by K. Hyland (2015, 510; see also Montgomery, 2016, 202): "many universities in Finland, Norway, and Sweden, in fact, have formulated language policies to promote parallel literacy among both staff and students, so that the national language is used together with English in research and teaching". The parallel use of the national and English language in academic communication by the Scandinavian countries contributes to the development of the national and English language of science; however, the suitability of the Scandinavian model in the Latvian situation is still to be assessed in the future. For example, the Latvian scientific journals Letonica, Latvian Institute of History Journal and Religious - philosophical articles, etc., publish articles in English and thus potentially lose even more of their local audience (Zanders, 2019, Dec 2). The mission of scientists is to disseminate their research results both to colleagues in the field and to other interested parties within the international and national environment. Anna Duszak (1997, p. 23) stresses that the dissemination of research results does not always occur purely for internationalisation purposes: "as understood as dealing with a topic, (1) what it implements in statements and various types of texts; (2) involving a more or regional community, expertise in an international community is a matter of delivering recognised products, putting them in circulation, and receiving feedback. On the other hand, a multilingual academic community may attract field experts who are not members proper. (...) As a result, they don't participate in the dialogue within that community". It follows from the foregoing that parallel use of languages represents both gains and losses in scientific communication at the national level.

One of the offered solutions concerns the translation of the promotion paper into English or Latvian. If the language of the doctoral thesis is English, its translation into Latvian contributes to the development of scientific terminology in Latvian. If a dissertation is translated from Latvian into English, it is possible to attract foreign experts to evaluate the dissertation and disseminate the research findings in the international scientific space. Creative union representative Matulis and Chairman of the Latvian Writers' Union Arno Jundze support the translation of doctoral theses: on the one hand, it would benefit the translators, but on the other hand, the translation services will cause additional costs. They could be covered by the doctoral student, university or government itself (LETA, 2019b, Dec 4; Jundze, 2019, Nov 20). However, the process is relatively expensive, and the Minister of Education and Science Ilga Suplinska believes that it is not necessary to produce a fully bilingual dissertation, but that the international availability of the study can be attested to by the degree applicant's publications on the topic of the thesis (LETA, 2019b, Dec 4). Hence 
the suggestion to permit a choice of the language of the doctoral thesis, which should be left to the universities (LETA, 2019b, Dec 4) or PhD student (LJZA, 2019, Dec 10; LIZDA, 2019, Nov 27).

The English language as the language for dissertations is mainly supported by representatives of natural sciences. Ministry senior expert Brigita Kukjalko claims that the proposal for a doctoral thesis in English has been made by natural sciences and engineering scholars on the basis of the increasing excellence and the international participation and inclusion of young scientists (Kuzmina, 2019a, Nov 20). At Riga Technical University one third of doctoral students write doctoral theses in English (TVNET/LETA, 2019, Nov 19). LJZA member Mārtinš̌ Liberts (2019, Nov 21) puts forward his suggestions for writing a thesis in English:

1) the terms are undergoing a process of agreement, and a summary of the thesis in Latvian serves to create new scientific terms;

2) science is international so the dissertation must be evaluated by one or two foreign experts (this suggestion is also supported by LJZA (2019, Dec 10));

3) the dissertation defence process prepares young scientists for international work;

4) a dissertation is written with a global purpose and will not only be valid locally.

In conclusion, M. Liberts (2019, Nov 21) thinks that English is the "de facto universal language of science at present". Also, A. Jundze (2019, Nov 20) evaluated arguments in favour of English in the natural sciences: science is one of the areas that is "fastest to be international, unifying, and is renouncing nationality for the sake of faster and easier communication". As a result, the "rating (citation) business" is also being promoted and profitable for publishing houses. He also concludes that English does not have an extensive enough vocabulary in natural science fields and states that "the formulas of mathematics or physics are the same in all languages". At the same time A. Jundze draws attention to the fact that the vocabulary of the humanities and social sciences is at least three or four times as large as that of the natural sciences, and that the effects of Anglicisation may lead to a weakening of the humanities. In addition, it is not always necessary to attract foreign reviewers for doctoral theses in the humanities and social sciences, as these reviewers do not always understand the national specifics of the research topic. Also, in the Alert Letter that was sent to the Ministry, mainly humanities and social sciences are against English as the only language of the doctoral thesis (TVNET/LETA 2019, Nov 19).

In general, it can be concluded that representatives of universities, research institutes and organisations brought different views into the discussion. The position of the Latvian language was defended, still allowing also the choice of the language of the doctoral thesis which could be determined by the university or doctoral student. The discussions also reflect the differing views of the natural sciences and humanities and social sciences on the language of the doctoral thesis in an international or national context. Obviously, the specificity of research in the field of science in an international or national context is significant, and the choice of the language of the doctoral thesis also depends on it. 


\section{LANGUAGE OF THE DOCTORAL STUDY PROCESS IN THE VIEW OF THE LATVIAN ONLINE COMMUNITY}

As we can see, there is a very diverse position among Latvian scientists and academics, which in most cases is also revealed and non-anonymously expressed in public. In this context, the question arises as to the views of the wider (anonymous) public, who are not directly concerned with this subject in their daily lives.

For this purpose, an empirical discourse content analysis approach has been chosen that allows to inductively define categories of a particular discourse (here the discourse on and around the language of the dissertation defence process in Latvia) to draw conclusions about socio-communicative practices in a given context. Discourse here, according to Andreas Gardt (2007, p. 26), is understood as dealing with a topic, (1) what it implements in statements and various types of texts; (2) involving a more or less large social group; (3) reflecting the knowledge and attitudes of this group to the issue; (4) while actively shaping it and thereby changing the social reality in the context of the issue. In the early days of empirical discourse and content analysis, the press, newspapers, etc. were widely used as sources. In recent years, there has been an increasing focus on online media, as well as on debates, discussions, communication in online media, which could be called online discourse.

In order to determine the opinion of the Latvian public regarding the language of the dissertation defence process and the role of the Latvian language as a science language, a qualitative analysis of the content of the online discourse was done. Qualitative Content Analysis corpus was selected from 10 web portals between November 19, 2019 and December 8th from articles posted about the Ministry's draft report and the related role of the Latvian language in science. Online media, or texts published online, have been selected for analysis because of the dynamic nature of online communication and its ability to quickly react to events. These considerations are based on the assumption that online discourse will aid extraction of information in order to infer public opinion about the language of the dissertation defence process in Latvia. A subtext type (genre) of 'reader comment' has been selected to determine public opinion "socially ratified way of using a language with a particular type of social activity" (Fairclough, 1995, p. 14). As a result, the corpus includes articles in which readers are actively engaged in communication by commenting on their views. Therefore, communication in online media article comments is no longer available as one-to-many communication, but it is gradually becoming interactive many-to-many (Albrecht, 2014) communication between larger groups of people or Online Community (on the difference between online Community, virtual community, and web community see Finster 2011, p. 18).

This study qualitatively analysed 304 mostly anonymous comments added as a reader's interactive response to an issue discussed in an online article to those already mentioned texts. It should be noted that the number of comments in these articles was quite different, from four to 87 (in the most discussed text 
on the subject) (data recorded on January 10, 2020). The limited number of comments ${ }^{1}$ could be an indication that the role of the Latvian language in the science space is relatively unimportant for the majority of the Online Community. Due to the small amount of data, the comments of the selected texts were analysed qualitatively, through continuous reading of the text, i.e., without the use of computer/digital tools.

Before analysing the content of the online discourse of the language of the dissertation defence process, it was clear that the comments on the articles of the web portals had two opposing positions: for and against the Latvian language in the $\mathrm{PhD}$ process. Given this assumption, it was important to identify the categories of reasoning that underlie these views, thereby gaining insight into the Latvian Online Community's dominant position in the language choice discourse within the PhD process.

The following is a discussion of the argumentative categories within the analysis, stance taken by users for/against the issue, illustrated with examples from the comments of anonymous readers.

As the first, the most frequently cited category of reader argumentation is noted Latvian vs. English language status. The proportion of readers who support English as the primary language of the $\mathrm{PhD}$ process mainly state that English should be considered lingua franca in the international community of scientists and academics: "Doctoral-level research and discoveries must be documented in English for worldwide access" (at Paiders 2019, Nov 22) or "Best literature available in English" (at LETA 2019a, Nov 27). Meanwhile, the arguments of the defenders of the Latvian language as a language of the dissertation defence process (as also seen in Part 2 above) express concern about the impact on the status of the language: "if the Latvian language is not in the advanced fields, the Latvian language will gradually become a second-class language" (at LLVA 2019c, Nov 28). Possibly influenced by the provocative titles of articles published on Internet portals, readers' comments also suggest that in such a situation the Latvian language could become a "low class" (peasant-like), household or conversation-only language.

In their language status arguments, English supporters explicitly state how this section of readers sees the role of both languages in Latvian higher education and science: "for important science in English, and for lectures for students in Latvian" (LETA, 2019b, Dec 4). Namely, commentators believe that the Latvian language will develop when a researcher prepares lectures and study materials based on their research for students in Latvian but publishes their papers in English.

Language usage and development is the next category of reasoning. For example, with the rhetorical question "what use does the country and language have from dissertations in English" (Paiders 2019, Nov 22) or the statement that there will be "no development in Latvian without scientific terms" (LETA 2019a,

1 Observations show that, for texts of public interest, reader's comments can reach 300 or more. It should be noted that no relevant research has been done in the Latvian media environment, so this should be considered as an individual observation of the authors. 
Nov 27) readers online point out the need to use language for all areas of life, and hence the language development directly related to it. Otherwise, the Latvian language will become a "stagnant, obsolete, profane language", down to a partial "death". In this category of reasoning, there is an aspect that goes beyond the scope of the dissertation process and the discourse of the language of science, considering the development of the Latvian language as the task of the whole nation: "in Latvia, our task is to develop the state language at all levels" (LETA $2019 b$, Dec 4). As a counterargument to this statement, it is stated that language development and retention will not be ensured through the PhD process, but that "care should be taken on a daily basis" (LETA 2019b, Dec 4).

Readers' comments have also highlighted the work and mission of the scientist. By supporting English as the language of the dissertation defence process, readers point to the publication of research results, citation, a wider readership, and greater visibility: "if we want our country to be seen as a highcalibre academic blacksmith, English (or other foreign language) in which the work can be read by speakers of other languages is, so to speak, "a must»" (at LETA 2019a, Nov 27). There is even a dramatic reference to the "fate" of a scientist's work if it is drafted in the local state language: "a work written in Latvian has disappeared for the rest of science" (LETA, 2019b, Dec 4). Some commentators take this situation of the change of $\mathrm{PhD}$ processing language to English as a possible step towards a change in the language used in the entire education system.

They see it as a starting point for the gradual transition of the entire education system to English: "what is the point of education in Latvian if foreign language is forced in such a way?" (LETA 2019a, Nov 27) or "if dissertations are written in English, the next step is higher education in English" (LETA 2019a, Nov 27).

Supporters of the English language also point out that the "most important function of the doctoral thesis is the contribution to world science, not the contribution to the Latvian language" (LETA, 2019b, Dec 4). In this regard, it is stated as a counter-argument that the aim of the scientific and doctoral studies is "general intellectual development of the people" (LETA, 2019a, Nov 27). In the broader context, it is concluded: "scientists must serve not only science but even more - life. In Latvia, scientific advancement papers must be written in Latvian" (at TVNET/LETA, 2019, Nov 19).

The last and most interesting category contains the arguments referring to the language as the cornerstone of a nation/country. The comments that support the Latvian language as the language of the dissertation defence process are permeated by references to the inseparable link between language and nation, or language as a key element of cultural identity. In the European context, of course, this does not highlight the Latvian nation against the background of all other nations. For example, as found by Pew Researcher Center in a study carried out in 2017, surveyed Europeans, unlike the respondents in other continents, stated that language was valued as a crucial component of their national identities (Stokes, 2017). Similarly, Latvian commentators directly associate language 
with the self-determination and existence of the Latvian people. For example, some readers believe that the "prohibition" of the Latvian language in the PhD process would be "genocide against the Latvian language and thus against the Latvian people" (LETA, 2019a, Nov 27) or "anti-Latvian" (Vìksne, 2019, Nov 20). The comments refer to discrimination, subordination of the nation and the nation: "(...) we lose the opportunity to be equal among other nations" (LLVA, 2019a, Nov 20). Alongside the link between language and people, another interesting aspect emerges in the argument, namely, the Latvian language as the cornerstone of the Latvian state/statehood: "the actual prohibition of the Latvian language in science is blatant harm to the Latvian state and the Latvian people". Some readers point to a return to the past: "we are losing an important conquest of the nation state - our national higher education and science (...)" (LLVA, 2019a, Nov 20). In this regard, there is also a collective memory, referring to the times of the former USSR, when the dissertation defence was only possible in Russian: "yes, it seems that the spiral circle has restarted. We are where we were before 1991. Only then did the dissertations have to be written in Russian. Now in English. And now we do it ourselves. Regrettable" (Kuzmina, 2019a, Nov 20).

As can be seen in this description of the results of qualitative content analysis of online discourse, the Latvian Online Community opinions differ radically on the issue described. The central arguments in favour of English as the language of the $\mathrm{PhD}$ process are language status and the work of the scholar, endlessly will highlight the benefits of a global science space, if the research paper is written in English (recognition, citability, communication with foreign colleagues, evaluation). In turn Online Community members who are for the Latvian language as a full-fledged language of the $\mathrm{PhD}$ process in their arguments mainly refer to the three categories described, with particular reference to the status of the Latvian language as an equivalent language (cultural identity) and Latvian statehood.

\section{CONCLUDING REMARKS}

Language choice is a complex matter for a scientist coming from a non-Anglophone space. Policy makers, as discussed in this paper, do not always think about the variety of consequences and public outcry after not too well thought out proposals of change in education policy. Within such rushed documents they do not take the time to ask all involved stakeholders - the doctoral students and their universities about what should be done based on their needs and observations. Latvian science will not reach excellence only because the doctoral dissertations are written in English; it should reach excellence because of great research that is not influenced by language choice alone.

The events of late last year show that the language situation is a fragile formation and its stability can easily be swayed by a single ill-thought-out and incompletely drafted Ministry-published document, whose creators see only one part without seeing other processes and predicting long-term consequences. The language of a state, which is protected by law and whose right to 
exist for everyone seems so obvious, can easily be placed in a potentially fragile situation if at least one of its functions is compromised; in this case it is the use of the state language in science.

In public discussions, representatives of the Ministry, universities and non-governmental organisations actively voiced their opinions on the issue of dissertation language, that is, English or Latvian. The biggest divide in opinions is found between the natural sciences and humanities and social science research and the proliferation of this research specifically on a national and global context that needs to be taken into account in the choice of dissertation language. Therefore, the choice should be left to the doctoral student, whereas a summary of the work written in a global science language or the national language would ensure that there is multilingualism in science that aligns with the Helsinki Initiative (Helsinki Initiative on Multilingualism in Scholarly Communication, 2020), and ensuring the further development of a national language of science.

Unlike the swift reaction of various professionals, no matter which stance they had taken, the stance of the Latvian public or the active Latvian Community and its involvement in the discussion is relatively passive. This was shown by the seemingly small number of comments under online articles describing the situation. However, it should be noted that the Latvian Online Community in this Ministry attempt to undermine the Latvian language as a language of science did see it as a threat to the status of the language, its overall unlimited usage and development. And if this is taken a step further - the limitation of the usage of Latvian in science could threaten one of the cornerstones of national identity and the statehood of Latvia.

The fight was fought and a compromise was reached. However, the still unresolved issue is that the Ministry, which should take care of the existence and development of public education and science in Latvia - a state with its own national language - allowed such language discrimination with far-reaching destructive consequences by the means of just one draft document.

\section{REFERENCES}

[1] Albrecht, S. (2014). Der emergente Diskurs im Internet: Wahrnehmung im Internet der Nanotechnologie im Spiegel der Online-Diskursanalyse. In: C. Fraas, S. Meier, \& C. Pentzold (Eds.). Online-Diskurse. Theorien und Methoden transmedialer Online-Diskursforschung (pp. 364-403). Köln: Herbert von Halem Verlag.

[2] Altbach, P. G. (2013). The International Imperative in Higher Education. Brill: Sense.

[3] Anstrate, V. (2019). Ministrija sola saglabāt valsts valodu zinātnē [The Ministry promises to preserve the Latvian language in science]. LSM.LV, Dec 4. Retrieved Jan 22, 2020 from https:/ / www.lsm.lv/raksts/zinas/latvija/ministrija-sola-saglabat-valsts-valodu zinatne.a340606/

[4] APA (2020). APA Dictionary of Psychology. Retrieved Feb 5, 2020. From https:/ / dictionary.apa. org/balanced-bilinguali

[5] Bennet, K. (2015). Towards an epistemological monocultureMechanisms of epistemicide in European research publications. In: R. Plo Alastrué, \& C. Pérez-Lantada (Eds.). English as a Scientific and Research Language (pp. 9-3: 5). Berlin: de Gruyter.

[6] Curry, M. J., \& Lillis, T. (2007). The dominance of English in global scholarly publishing. International Higher Education, 46. Retrived May 15, 2020 from https://doi.org/10.6017/ ihe.2007.46.7948 
[7] Čìka, I. (2019). Neatkarīgā izglīìibas biedrība: Promocijas darbu vērtỉba var „pazust tulkojumā" [Independent Education Society: The value of dissertations could be "lost in translation"]. LETA, Dec 8. Retrieved Jan 20, 2020 from https://skaties.lv/zinas/latvija/ politika/neatkariga-izglitibas-biedriba-promocijas-darbu-vertiba-var-pazust-tulkojuma/

[8] Duszak, A. (1997). Cross-cultural academic communication a discourse - community view. In: A. Duszak (Ed.): Culture and Styles of Academic Discourse (pp. 11-39). Berlin; New York: de Gruyter.

[9] European Commission (2014). Conclusions on multilingualism and the development of language competences. Retrieved Feb 5, 2020 from https://www.consilium.europa.eu/ uedocs/cms_ data/docs/pressdata/en/educ/142692.pdf

[10] Fairclough, N. (1995). Critical discourse analysis. The critical study oflanguage. London: Longman.

[11] Finster, D. (2011). Online Communities. Geschäftsmodelle unter dem Einfluss des Electronic Commerce. Hamburg: Diplomica Verlag.

[12] Gardt, A. (2007). Diskursanalyse. Aktueller theoretischer Ort und methodische Möglichkeiten. Retrieved Jan 20, 2020 from https://www.uni-kassel.de/fb02/fileadmin/datas/fb02/ Institut_f\%C3\%BCr_Germanistik/Dateien/DISKURSANALYSE_gardt.pdf

[13] Helsinki Initiative on Multilingualism in Scholarly Communication. (2020). Retrieved Feb 5, 2020 from https:// www.helsinki-initiative.org/en/info

[14] Hyland, K. (2015). Academic Publishing. Issues and Challenges in the Construction of Knowledge. Oxford: University Press.

[15] IZM (2019). Par konceptuāli jauna doktorantūras ietvara un jauna promocijas procesa ieviešanu Latvijā: projekts [Conceptual Report about a conceptually new doctoral studies framework and dissertation defence process in Latvia: Draft]. Rīga: IZM.

[16] Jundze, A. (2019). Vai latviešu valodas bēres? [A funeral for the Latvian language?]. NRA.LV, Nov 20. Retrieved Feb 5, 2020 from https:/ / nra.lv/latvija/297551-vai-latviesu-valodas-beres.htm

[17] Kasparāns, Ģ. (2019). Valdis Muktupāvels: Ar vēlmi eksperimentēt mums viss ir kārtībā [intervija] [Valdis Multupāvels: Our urge to experiment is fine]. LA.LV, Oct 27. Retrieved Jan 20, 2020 from https:/ / www.la.lv/tautas-muzika-ir-dziva

[18] Kuzmina, I. (2019a). Vai nākotnē latviešu valoda būs tikai ķēķa valoda? [Will Latvian be used only at home in the future?]. LA.LV., Nov 20, Retrieved Feb 5, 2020 from https://www.la.lv/ bazijas-par-latviesu-valodas-vietu-zinatne

[19] Kuzmina, I. (2019b). Latviešu valoda zinātnē nosargāta? [Latvian has been protected in science?]. LA.LV., Dec 8, Retrieved Feb 5, 2020 from https://www.la.lv/ latviesu-valoda-zinatne-nosargata

[20] Langin, K. (2019). For academics, what matters more: journal prestige or readership? Washington: American Association for the Advancement of Science (AAAS). Retrieved 15 May, 2020 from doi:10.1126/science.caredit.aay8817

[21] Latvian Public Broadcasting/ LTV (2019). Will future of doctoral theses be in Latvian or English? LSM.LV, Nov 20. Retrieved Jan 22, 2020 from https://eng.lsm.lv/article/society/ education/will-future-of-doctoral-theses-be-in-latvian-or-english.a338990/

[22] Law of Scientific Activity (2005). Retrieved Jan 20, 2020 from https://likumi.lv/ ta/en/en/ id/107337

[23] LETA (2019a). Atklātā vēstulē iebilst pret IZM jauno doktorantūras modeli [Objections against the Education and Science Ministry's new model of doctoral studies are voiced in an open letter]. DELFI.LV, Nov 27. Retrieved Jan 10, 2020 from https://www.delfi.lv/ news/national/ politics/atklata-vestule-iebilst-pret-izm-jauno-doktoranturas-modeli.d?id=51674165

[24] LETA (2019b). Akadēmiskajam personālam nav vienprātỉbas par latviešu valodas lomu promocijas darbos [Academics are not unanimous about the role of the Latvian language in doctoral dissertations] DELFI.LV, Dec 4. Retrieved Feb 5, 2020 from https://www.delfi.lv/news/ national/politics/akademiskajam-personalam-nav-vienpratibas-par-latviesu-valodas-lomupromocijas-darbos.d?id $=51692495$

[25] Liberts M. (2019). Promocijas darbs latviski vai angliski? [Doctoral dissertation in Latvian or English?]. Nov 21. Retrieved Feb 5, 2020 from https://djhurio.wordpress. com/2019/11/21/ promocijas-darbs-latviski-vai-angliski/

[26] LIZDA (2019). Inga Vanaga: jāḷauj doktorantiem izvēlēties, kādā valodā rakstīt promocijas darbu [Inga Vanaga: Doctoral students should be given a language choice for their disserta- 
tion]. LIZDA.LV, Nov 27. Retrieved Feb 5, 2020 from https:/ /www.lizda.lv/ current_events/ inga-vanaga-jalauj-doktorantiem-izveleties-kada-valoda-rakstit-promocijas-darbu/

[27] LJZA (2019). LJZA komentārs par valodas prasībām promocijas darbam [LJZA commentary about the requirements of a doctoral dissertation]. LJZA.LV, Dec 10. Retrieved Feb 5, 2020 from http://ljza.lv/ljza-komentars-par-valodas-prasibam-promocijas-darbam/

[28] LLVA (2019a). Latviešu valodas pozīiju stiprināšana vai graušana? [Strenghtening or destruction of the Latvian language?]. IR.LV, Nov 20. Retrieved Jan 10, 2020 from https:/ / ir.lv/2019/11/20/latviesu-valodas-poziciju-stiprinasana-vai-to-grausana

[29] LLVA (2019b). Ministrija sola promocijas procesu valsts valodā [The Ministry promises a dissertation defense procedure in the state language]. Dec 11. Retrieved Feb 5, 2020 from http:/ /lva. lv/2019/12/11/ministrija-sola-promocijas-procesu-valsts-valoda/

[30] LLVA (2019c). Trauksmes vēstule par bezprecendenta draudiem latviešu valodas nākotnei [Alert Letter about a non-precendented level of threat against the future of the Latvian language]. IR.LV, Nov 28. Retrieved Jan 10, 2020 from https://ir.lv/2019/11/28/ trauksmes-vestule-par-bezprecedenta-draudiem-latviesu-valodas-nakotnei/

[31] Montgomery, S. L. (2016). Impacts of a Global Language on Science. Are There Disadvantages? In: M. MacLeod, R. G. Sumillera, J. Surman, \& E. Smirnova (Eds.): Language as a Scientific Tool. Shaping Scientific Language Across Time and National Tradition (pp. 199-218). New York; London: Routledge.

[32] Muktupāvela, R. (2015). Etniskums globalizācijas laikmetā: mazākumtautību seminārs. [Ethnicity in the age of globalisation: a seminar for minority groups.]. [Prezentācija]. Retrieved Jan 19, 2020 from http://belorus.lv/wp-content/uploads/2015/06/Muktipavele_ Mazakumtautibu-seminars-2015.pdf

[33] Official Language Law (1999). Retrieved Jan 20, 2020 from https://likumi.lv/ta/en/en/id/ 14740

[34] Paiders, J. (2019). Steidzami jāmaina Satversmes preambula un 4. pants! [Paragraph 4 of the Latvian Constitution should be changed immediately!]. NRA.LV, Nov 22. Retrieved Jan 20, 2020 from https://nra.lv/viedokli/juris-paiders-3/297744-steidzami-jamaina-satversmespreambula-un-4-pants.htm

[35] Phillipson, R. (1992). Linguistic Imperialism. Oxford: Oxford University Press.

[36] Runce, I. (2013). Latgales teritoriālā identitāte glokalizācijas un globalizācijas krustceḷos [The Territorial Identity of Latgale in the Crossroads of Glocalization and Globalization]. Via Latgalica: humanitāro zinātņu žurnāls (pp. 81-85). Rēzekne: Rēzeknes Augstskola.

[37] Sivertsen, G. (2018). Balanced multilingualism in science. BiD: textos universitaris de biblioteconomia i documentació, 40. Retrieved Feb 5, 202081-85 from http://bid.ub.edu/en/40/ sivertsen.htm, DOI: http://dx.doi.org/10.1344/BiD2018.40.25

[38] Stokes, B. (2017). 1. Language: The cornerstone of national identity. Pew Researcher Center. Retrieved Jan 25, 2020 from https://www.pewresearch.org/global/2017/02/01/ language-the-cornerstone-of-national-identity/

[39] The Constitution of the Republic of Latvia (1922). Retrieved Jan 20, 2020 from https:/ likumi.lv/ ta/en/en/id/57980-the-constitution-of-the-republic-of-latvia

[40] TVNET/LETA (2019). Kādā valodā jāraksta promocijas darbi? IZM piedāvā - vismaz angliski [What language should dissertations be written in? The Ministry of Education and Science says - at least in English]. TVNET.LV, Nov 19. Retrieved Jan 10, 2020 from https://www. tvnet.lv/6829876/kada-valoda-jaraksta-promocijas-darbi-izm-piedava-vismaz-angliski

[41] Vīksne, I. (2019). Inteliǵence mobilizējas valsts valodas aizsardzībai [The Intelligentsia mobilises itself for the defence of the state language]. NRA.LV, Nov 20. Retrieved Feb 5, 2020 from https://nra.lv/latvija/izglitiba-karjera/297530-inteligence-mobilizejas-valsts-valodasaizsardzibai.htm

[42] Wheeler, A. G. (1989). The Pressure to Publish Promotes Disreputable Science. The Scientist. Retrieved Feb 5, 2020 from https://www.the-scientist.com/opinion-old/ the-pressure-to-publish-promotes-disreputable-science-61944

[43] Zanders, M. (2019). Zinātne latviešu valodā - provinciālisms? [Science in Latvian provincial?]. Satori.lv, Dec 2. Retrieved Feb 5, 2020 from https://satori.lv/article/ zinatne-latviesu-valoda-provincialisms 